\title{
APAKAH BANK SYARIAH BERBEDA DENGAN BANK KONVENSIONAL? (KAJIAN FENOMENOLOGI)'
}

\author{
Tyagita Winaya Mukti \\ Departemen Ekonomi Syariah- Fakultas Ekonomi dan Bisnis-Universitas Airlangga \\ Email : tyagitawinaya@gmail.com \\ Noven Suprayogi \\ Departemen Ekonomi Syariah- Fakultas Ekonomi dan Bisnis-Universitas Airlangga \\ Email : Noven2005@gmail.com
}

\begin{abstract}
:
The purpose of this research is to find similarities and differences of sharia bank and convenstional bank's financial systems from bank employee's perspective. This study use qualitative method with fenomenology approach because it describes the general meaning of several individuals toward their various life experiences related to the concept or phenomenon.. The data used in this research are primary data that obtained through indepth interview with bank employee and secondary data that obtained form of documentation study to be done triangulation data. The main focus in this study is describe what are the similarities and differences of financial system in sharia bank and conventional bank of what is happening in the reality. The results of this study indicate that the similarity of financial system is drawn from the experience of bank employees who have worked in sharia and conventional banks derived from the type of product and its function as a financial institution. Meanwhile, the difference of sharia and conventional banks derived from the profit taking and system.In reality, sharia and conventional banks are different in terms of religion point of view, while the contracts and the economic substance of those two banks are the same.
\end{abstract}

Keywords: financial system, sharia bank, conventional bank, bank employee

\section{PENDAHULUAN}

\section{Latar Belakang}

Sebagai negara berkembang, Indonesia sangat membutuhkan keberadaan bank, ditambah lagi dengan teknologi sudah semakin maju maka produk-produk yang ditawarkan oleh bank sangat bermanfaat untuk mendukung gerak roda perekonomian negara. Bank merupakan salah satu lembaga keuangan yang mempunyai peranan penting di dalam perekonomian suatu Negara sebagai lembaga perantara keuangan. Bank diatur dalam
Undang-Undang Republik Indonesia Nomor 10 Tahun 1998 tentang perubahan atas Undang-Undang Republik Indonesia Nomor 7 Tahun 1992 tentang perbankan. Pada tahun 2008 dalam perbankan Indonesia hadir perbankan syariah dengan disahkannya UndangUndang Nomor 21 Tahun 2008 tentang Perbankan Syariah. Berlakunya undangundang ini dalam system perbankan Indonesia menjadi dual banking system yaitu system perbankan konvensional berdasarkan Undang-Undang Nomor 10 tahun 1998 dan system perbankan syariah berdasarkan Undang-Undang Nomor 21

\footnotetext{
${ }^{1}$ Jurnal ini merupakan bagian dari skripsi Tyagita Winaya Mukti, NIM: 041411431120 , yang diuji pada tanggal 20 Juli 2018.
} 
Tahun 2008 yang berjalan secara berdampingan. Dual banking system atau sistem perbankan ganda merupakan terselenggaranya dua sistem perbankan yaitu konvensional dan syariah secara bersama-sama. Sistem perbankan syariah dan perbankan konvensional secara sinergis dapat mendukung mobilisasi dana masyarakat secara lebih luas untuk meningkatkan kemampuan pembiayaan bagi sektor-sektor perekonomian nasional. Sistem perbankan konvensional yang telah ada sebelumnya semakin lengkap dengan adanya system perbankan syariah, sehingga diharapkan dapat memenuhi kebutuhan semua elemen masyarakat akan jasa perbankan tanpa perlu ragu lagi mengenai boleh atau tidaknya memakai jasa perbankan, terutama jika ditinjau dari kacamata agama. Bahkan yang menjadi kritik sistem perbankan syariah yang terhadap perbankan konvensional bukan dalam hal fungsinya sebagai lembaga intermediasi keuangan (financial intermediary institution), tetapi karena di dalam operasionalnya masih terdapat unsurunsur yang dilarang.

Bank konvensional dan bank syariah dalam beberapa hal memiliki persamaan, terutama dalam sisi teknis penerimaan vang, mekanisme transfer, teknologi komputer yang digunakan, syarat-syarat umum meperoleh pembiayaan seperti KTP, NPWP, proposal, laporan keuangan, dan sebagainya. Perbedaan mendasar diantara kedua bank tersebut yaitu menyangkut aspek legal, struktur organisasi, usaha yang di biayai dan lingkungan kerja (Antonio, 2001).

Terdapat banyak perbedaan dasar antara bank konvensional dengan bank syariah. Perbedaan itu menyangkut aspek legal, struktur organisasi, usaha yang dibiayai, dan lingkungan kerja. Perbedaan lain diantara keduanya yaitu terletak pada prinsip yang digunakan. Bank konvensional menggunakan bunga dalam beroperasi serta berprinsip meraih untung sebesar-besarnya sedangkan bank syariah beroperasi menggunakan prinsip bagi hasil untuk menghindari riba. Selain itu pada Bank syariah terdapat dewan pengawas syariah sedangkan bank konvensional tidak ada. Berikut ini adalah ayat $\mathrm{Al}$ Qur'an yang melandasi berdirinya bank syariah :

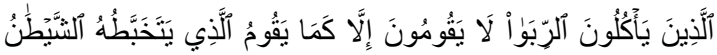

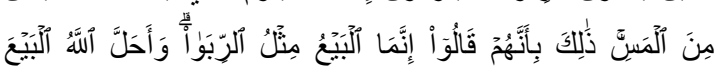

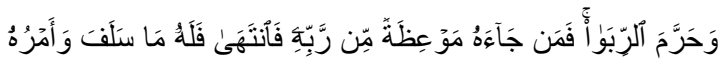

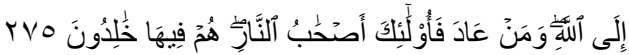

Artinya: Orang-orang yang memakan ribatidak dapat berdiri melainkan seperti berdirinya orang yang kemasukan syaitan karena gila.Yang demikian itu karena mereka berkata bahwa jual-beli sama dengan riba. Padahal, Allah telah menghalalkan jual beli dan mengharamkan riba. Barang siapa yang mendapat peringatan dari Tuhannya, lalu dia berhenti, maka baginya apa yang telah diambilnya dahulu(sebelum datang larangan); dan urusannya (terserah) 
kepada Allah. orang yang kembali (mengambil riba), maka apa yang telah diperolehnya dahulu menjadi miliknya dan urusannya (terserah) kepada Allah. Barang siapa mengulangi, maka mereka itu penghuni neraka, maka kekal di dalamnya. (Q.S. 2: 275, Departemen Agama Rl. 2007:47)

$$
\text { Muhammad Hanif }
$$

melakukan penelitian dengan judul "Economic substance or legal form: an evaluation of Islamic finance practicedalam Jurnal Internasional keuangan Islam dan Timur Tengah dan manajemen menyimpulkan praktik terhadap teori sistem keuangan Islam ditemukan bahwa kontrak lembaga kevangan Islam sejalan dengan teori sejauh posisi hukum yang bersangkutan. Namun substansi ekonomi tidak berbeda dari perbankan konvensional. Persamaan dengan penelitian ini adalah penggunaan perbankan sebagai objek penelitian. Sedangkan perbedaannya adalah penelitian ini membahas analisis persamaan dan perbedaan sistem keuangan bank syariah dan bank konvensional di Indonesia. Analisis tentang perbedaan dan persamaan sistem keuangan di bank konvensional dan bank syariah dengan pendekatan fenomenologi menggunakan subjek yang berbeda yaitu berdasarkan perspektif pegawai bank yang bekerja di bank konvensional lalu pindah bekerja di bank syariah, begitu juga sebaliknya pegawai

bank yang bekerja di bank syariah dan pindah bekerja di ban konvensional.

Alasan peneliti melakukan penelitian kualitatif dengan pendekatan fenomenologi untuk mendeskripsikan pemaknaan umum dari sejumlah individu terhadap berbagai pengalaman hidup mereka terkait dengan konsep atau fenomena. Melihat pengalaman dan perilaku sebagai suatu kesatuan yang tidak dapat dipisahkan, baik itu kesatuan antara subjek dan objek, maupun antara bagian dan keseluruhannya. Dengan mengeksplorasi masalah sosial dan manusia, peneliti membangun sebuah masalah kompleks dan menyeluruh dalam menganalisa kata-kata dan melaporkan secara detail pandangan pegawai bank.

Fenomenologi adalah ilmu tentang gejala atau hal-hal apa saja yang tampak. Namun perlu dipahami dengan sungguh-sungguh bahwa suatu fenomena pada hakikatnya suatu kesadaran dan interaksi atas apa yang diamati sebagai sesuatu set terpisah dari pengamat (observer). Dengan demikian pengamat betul-betul yakin hasil pengamatan dan analisis interaktif itu, itulah sikap yang sesungguhnya dan alami (natural attitude) (Yusuf, 2014).

\section{LANDASAN TEORI}

Bank

Pengertian bank secara
sederhana dapat diartikan sebagai
lembaga kevangan yang kegiatan
utamanya adalah menghimpun dana
dari masyarakat dan menyalurkannya


kembali dana tersebut ke masyarakat serta memberikan jasa bank. Kemudian pengertian bank menurut UndangUndang RI Nomor 10Tahun 1998 tanggal 10 November 1998 tentang Perbankan adalah badan usaha yang menghimpun dana dari masyarakat dalammenyimpanbentuk simpanan dan menyalurkannya kepada masyarakat dalam bentuk kredit dan atau bentukbentuk lainnya dalam rangka meningkatkan taraf hidup rakyat banyak (Kasmir, 2010)

Bank merupakan perusahaan yang bergerak dalam bidang keuangan, artinya usaha perbankan selalu berkaitan masalah bidang keuangan. Jadi dapat disimpulkan bahwa usaha perbankan meliputi tiga kegiatan utama yaitu:

1. Menghimpun dana.

2. Menyalurkan dana.

3. Memberikan jasa bank lainnya.

\section{Bank Syariah}

Bank syariah merupakan bank yang dalam pengoperasian dan sistem keuangannya disesuaikan dengan prinsip Islam. Bank syariah melakukan kegiatan usaha berdasarkan bagi hasil. Dalam melakukan kegiatan usaha tersebut diberikan kebebasan untuk mengembangkan produk penghimpunan dana serta pelayanan jasa perbankan syariah (Usman, 2012:49). Pengembangan sistem perbankan syariah di Indonesia dilakukan dalam kerangka dual banking system atau yang biasa disebut sistem perbankan ganda untuk menghadirkan alternatif jasa perbankan yang semakin lengkap kepada masyarakat Indonesia.Dasar pembentukan bank syariah bersumber dari larangan riba dalam Al Qur'an dan Hadits. Pengharaman riba dalam Al Qur'an melalui empat tingkatan yaitu pada QS. ar-Ruum ayat 39, QS. an-Nisa ayat 160, QS. Ali Imran ayat 130, dan QS. al-Baqarah ayat 275 .

\section{Fungsi Bank}

Julius (2012:135) menjelaskan fungsi lain dari bank selain fungsi utama sebagai lembaga intermediari antara lain:

1. Agent of Trust

Fungsi ini menunjukkan bahwa aktivitas intermediasi yang dilakukan oleh dunia perbankan dilakukan berdasarkan asas kepercayaan, dalam pengertian bahwa kegiatan pengumpulan dana yang dilakukan oleh bank tentu harus didasari rasa percaya dari masyarakat atau nasabah terhadap kredibilitas dan eksistentsi dari masing-masing bank, karena tanpa rasa percaya masyarakat tidak akan menitipkan dananya di bank yang bersangkutan. Kepercayaan meliputi konsistensi dan kejujuran nasabah dalam menggunakan kredit yang diberikan. Aspek kepercayaan juga berkaitan dengan kemampuan nasabah untuk membayar kembali pinjaman yang diterimanya.

2. Agent of Development 
Fungsi ini sangat berkaitan dengan tanggung jawab bank dalam menunjang kelancaran transaksi ekonomi yang dilakukan oleh setiap pelaku ekonomi. Dalam kegiatan ekonomi kita ketahui bahwa kegiatan produksi, distribusi, dan konsumsi merupakan satu kesatuan yang tidak terpisah. Bank sebagai lembaga keuangan tentu mempunyai peran yang sangat strategis, sehingga dari aspek ini bank berfungsi untuk menjembatani semua kepentingan pelaku ekonomi dalam transaksi ekonomi yang dilakukan.

3. Agent of Service Industri perbankan adalah lembaga yang bergerak di bidang jasa keuangan maupun jasa non keuangan. Sebagai bank, di samping memberikan pelayanan jasa kevangan sebagaimana kegiatan intermediasi yang selalu dilakukan, maka bank juga turut serta dalam memberikan jasa pelayanan yang lain seperti jasa transfer (payment order, jasa kotak pengaman (safety box), jasa penagihan, atau inkaso (collection) yang saat ini telah mengalami perubahan dengan nama city clearing. Dengan pemahaman ini maka dapat diketahui bahwa sesungguhnya bank tidak hanya dipahami dalam kedudukannya sebagai lembaga intermediasi semata-mata, tetapi juga memiliki fungsi-fungsi lainnya.

\section{Dual Banking System}

Dual banking system atau sistem perbankan ganda merupakan terselenggaranya dua sistem perbankan yaitu konvensional dan syariah secara bersama-sama. Sistem perbankan konvensional yang telah ada sebelumnya semakin lengkap dengan adanya sistem perbankan syariah, sehingga diharapkan dapat memenuhi kebutuhan semua elemen masyarakat akan jasa perbankan tanpa perlu ragu lagi mengenai boleh atau tidaknya memakai jasa perbankan, terutama jika ditinjau dari kacamata agama. Bahkan yang menjadi kritik sistem perbankan syariah yang terhadap perbankan konvensional bukan dalam hal fungsinya sebagai lembaga intermediasi keuangan (financial intermediary institution), tetapi karena di dalam operasionalnya masih terdapat unsurunsur yang dilarang.

\section{Sistem Keuangan Bank}

Sistem kevangan adalah sebuah set interaksi kompleks antara institusi kevangan dan pasar yang menyalurkan dana untuk investasi dan penyediaan fasilitas, termasuk sistem pembayaran dan pendanaan kegiatan komersial (International Monetary Fund, 2006). Sistem ini menyediakan fasilitas bagi pihak kekurangan dana dan pihak kelebihan dana untuk memenuhi kebutuhannya. Pelaku utama sistem ini tidak hanya institusi keuangan seperti bank komersial, bank sentral, asuransi, lembaga sekuritas dan lain-lain, tetapi institusi yang secara 
langsung dan tidak langsung berkaitan dengan institusi keuangan, seperti rumah tangga, institusi nonfinansial, pemerintah, sektor publik, pasar finansial, dan properti.

Lembaga perbankan mempunyai peranan dan strategis tidak hanya dalam menggerakkan roda perekonomian nasional, tetapi juga diarahkan agar mampu menunjang pelaksanaan pembangunan nasional. Ini berarti bahwa lembaga perbankan haruslah mampu berperan sebagai agent of development dalam upaya mencapai tujuan nasional itu, dan tidak menjadi beban dan hambatan dalam pelaksanaan pembangunan nasional.

\section{Sistem Keuangan Islam}

Sistem kevangan Islam berbeda dengan sistem keuangan konvensional. Keuangan Islam didasarkan pada syariat (hukum Islam). Ulama telah mengidentifikasi tujuan syariah termasuk keselamatan iman, kehidupan, properti, keturunan, intelek (Siddiq, 2010). Menurut Muhammad Hanif (2016) dalam jurnal Economic substance or legal form: an evaluation of Islamic finance practice, prinsip-prinsip keuangan Islam telah didokumentasikan oleh para ulama:

1. Pelarangan bunga dan riba dalam transaksi keuangan.

2. Menghindari gharar (ketidakjelasan)

3. Menghindari maysir (spekulasi).

4. Profit and loss sharing.

5. Pendanaan untuk bisnis yang halal.

Model Bisnis Bank (Commercial Banking)
Salah satu tipe model bisnis perbankan adalah berdasarkan activity. Tipe model bisnis activity yang dimaksud ialah kegiatan utama perbankan yang digunakan secara umum di industri perbankan yaitu kegiatan bank sebagai bank investasi (investement banking), kegiatan bank umum (commercial banking), dan kegiatan bank universal (universal banking). Bank komersial adalah apa yang disebut orang dengan kata "bank" yaitu badan usaha yang menghimpun dana dari masyarakat dalam bentuk simpanan dan menyalurkannya kepada masyarakat dalam bentuk kredit dan atau bentukbentuk lainnya dalam rangka meningkatkan taraf hidup orang banyak.

\section{Karakter Bisnis Bank Syariah}

Karakter bisnis yang dimiliki bank syariah adalah:

1. Customer Segment Perbankan Syariah di Indonesia

$\begin{array}{ccr}\text { Secara } & \text { smum, } \\ \text { pembiayaan nasabah perbankan }\end{array}$
syariah di Indonesia didominasi oleh pembiayaan konsumtif, kemudian diikuti dengan pembiayaan produktif. Bank Syariah memiliki kriteria dari masing-masing segmen nasabah.

Perkembangan pasar dan potensi bank syariah di berbagai negara termasuk juga di Indonesia menuntut dilakukannya diversifikasi produk, layanan dan model bisnis bank syariah yang kompetitif di tingkat global dan pasar lokal. Besarnya 
potensi pasar di Indonesia membuat industri perbankan berlomba-lomba membuka layanan bisnis syariah.

2. Offering (Value Preposition) Perbankan Syariah di Indonesia

Perbankan syariah terus berinovasi dan berbenah diri untuk meningkatkan variasi, kualitas, dan kemanfaatan produk dan layanan perbankan dan keuangan bagi nasabahnya.

3. Infrastruktur Perbankan Syariah di Indonesia

Infrastruktur merupakan kebutuhan fisik yang penting bagi sebuah organisasi atau perusahaan dalam proses berlangsungnya kegiatan operasional. Terdapat banyak elemen dari infrastruktur perusahaan, seperti sumber daya manusia, teknologi informasi, jaringan kantor, dan sebagainya. Bentuk outlet layanan perbankan syariah juga sangat beragam mulai dari kantor bank, ATM, internet dan mobile banking, dan bentuk-bentuk kerjasama delivery channel lainnya yang akan terus ditingkatkan guna mempermudah penyediaan layanan jasa bank syariah bagi seluruh masyarakat.

4. Financing

Produk utama perbankan syariah yang umumnya ditawarkan menggunakan skema Debt Based Financing (murabahah dan ijarah). Bagi perbankan, produk-produk tersebut juga menjadi produk favorit bank, dikarenakan skema transaksinya yang mudah diterapkan dan tidak berisiko tinggi.

\section{METODE PENELITIAN}

Penelitian ini menggunakan metode kualitatif dengan pendekatan fenomenologi pada prinsipnya ingin memberikan, menerangkan, mendeskripsikan secara kritis, atau menggambarkan suatu fenomena, suatu kejadian, peristiwa interaksi sosial dalam masyarakat untuk mencari dan menemukan makna (meaning) dalam konteks yang sesungguhnya (natural setting). Oleh karena itu semua jenis penelitian kualitatif bersifat deskriptif, dengan mengumpulkan data lunak (soft data), bukan hard data yang akan diolah dengan statistik.

Penelitian ini bersifat menggali suatu fenomena serta mengungkapkan kejadian dibalik pengalaman hidup seseorang terkait konsep atau fenomena, maka penelitian kualitatif dengan pendekatan fenomenologi penting dilakukan untuk mengetahui secara lebih rinci dan mendalam bagaimanapersamaan dan perbedaan sistem keuangan bank syariah dan bank konvensional dari perspektif pegawai bank, sehingga hasil dari penelitian ini diharapkan memberi manfaat bagi perbankan dan pelaku didalamnya dalam melakukan sistem keuangan di bank. Penelitian ini dapat memberikan pengetahuan bagi masyarakat dan 
membenarkan persepsi yang salah terkait sistem keuangan di bank syariah dan bank konvensional di Indonesia yang menganut dual banking system.

\section{Ruang Lingkup Penelitian}

Ruang lingkup penelitian dan batasan penelitian ini adalah persamaan dan perbedaan sistem kevangan terkait produk, penghimpunan dana, dan penyaluran dana di bank syariah dan bank konvensional dari perspektif pegawai bank menggunakan metode analisis kualitatif dengan pendekatan fenomenologi. Metode ini menganalisa persamaan dan perbedaan sistem keuangan bank syariah dan bank konvensional melalui perspektif pegawai bank yang sudah pernah bekerja di bank syariah maupun bank konvensional. Subjek dipilih secara purposive samplingberdasarkan aktivitas mereka dan kesediaan mereka untuk mengekplorasi dan mengartikulasikan pengalaman mereka secara sadar.

Wawancara dilakukan kepada 13 orang pegawai bank yang pernah pengalami kerja di bank syariah dan bank konvensional sebagai subjek penelitian sesuai dengan tradisi fenomenologis dimana jumlah subjek penelitian minimal sebanyak 10 orang.Subjek penelitian tersebut dijadikan informan utama atau sumber data utama atau Creswell menyebutnya partisipan.

\section{Jenis dan Sumber Data}

Sumber dan jenis data dalam penelitian berikut meliputi:
1. Data primer pada penelitian ini diperoleh dari hasil wawancara dengan key informan (informan kunci) untuk mengetahui fenomena yang terjadi secara mendetail, maka key informan pada penelitian ini adalah sebagai 13 orang pegawai bank yang pernah bekerja di bank syariah dan bank konvensional.

2. Data sekunder

Data sekunder merupakan data yang mendukung penelitian yang didapatkan secara tidak langsung dari suatu objek penelitian yang berupa arsip, laporan, dan dokumen yang relevan serta kajian pustaka yang berkaitan dengan penelitian. Data sekunder dalam penelitian ini diperoleh dari buku, jurnal, surat kabar, publikasi online, brosur, dan laporan kegiatan penelitian yang pernah dilakukan yang berkaitan dengan apa saja perbedaan dan persamaan bank syariah dan bank konvensional baik dari perspektif pegawai bank maupun dari perspektif lain yang relevan.

\section{Prosedur Pengumpulan Data}

Dalam penelitian ini, data diperoleh dari proses wawancara dengan informan yaitu pegawai bank yang pernah bekerja di bank syariah dan bank konvensional serta di posisi yang berkaitan dengan sistem keuangan pada kedua bank tersebut. Penelitian ini menggunakan metode pengumpulan data yang lain yaitu dokumen untuk 
meningkatkan kredibilitas temuan penelitian karena jika hanya menggunakan satu metode pengumpulan data dapat menyebabkan kesalahpahaman. Kombinasi dari metode-metode tersebut memungkinkan peneliti untuk menjelaskan bagaimana persamaan dan perbedaan sistem kevangan di bank syariah dan bank konvensional yang sesungguhnya beserta alasan-alasannya.

\section{Teknik Keabsahan Data}

Penelitian ini menggunakan triangulasi untuk menyelaraskan dan memeriksa keabsahan data. Triangulasi dalam pengecekan kredibilitas ini diartikan sebagai pengecekan data dari berbagai sumber dengan berbagai cara, dan berbagai waktu. Dalam penelitian ini menggunakan triangulasi sumber dan triangulasi teknik.

Triangulasi sumber untuk menguji kredibilitas data dilakukan dengan cara mengecek data yang telah diperoleh melalui beberapa sumber yaitu informan pada penelitian ini.Untuk menguji kredibilitas data tentang sistem keuangan bank syariah dan bank konvensional yang pernah dialami seorang pegawai bank, maka pengumpulan dan pengujian data yang telah diperoleh dari banyak pegawai bank yang pernah bekerja di bank syariah dan bank konvensional. Data-data tersebut dideskripsikan, dikategorisasikan, mana pandangan yang sama, yang berbeda, dan mana spesifik. Data yang telah dianalisis oleh peneliti sehingga menghasilkan suatu kesimpulan.

Sedangkan triangulasi teknik untuk menguji kredibilitas data dilakukan dengan cara mengecek data kepada sumber yang sama dengan teknik yang berbeda. Data yang diperoleh dengan wawancara dicek dengan dokumen. Bila dengan teknik pengujian kredibilitas data tersebut menghasilkan data yang berbeda-beda, maka peneliti melakukan diskusi lebih lanjut kepada sumber data yang bersangkutan atau yang lain, untuk memastikan data mana yang dianggap benar. Atau mungkin semuanya benar, karena sudut pandangnya berbedabeda.

\section{Teknik Analisis Data}

Menurut Engkus Kuswarno (2009) data dalam penelitian kualitatif antara lain berupa pernyataan, gejala, tindakan nonverbal yang dapat terekam oleh deskripsi kalimat atau oleh gambar, maka terdapat tiga alur kegiatan yang dapat dilakukan secara bersamaan, yaitu reduksi data, penyajian data, dan penarikan atau verifikasi.

1. Reduksi Data

Reduksi data adalah suatu proses pemilhan, pemusatan perhatian pada penyederhanaan, pada pengabstrakan dan transformasi data kasar yang muncul dari catatan-catatan tertulis di lapangan. Data kualitatif disederhanakan dan ditransformasikan dengan aneka 
macam cara, antara lain seleksi yang ketat, tingkasan atau uraian singkat, penggolongan dalam suatu pola yang lebih luas.

2. Penyajian data

Penyajian data adalah susunan sekumpulan informasi yang memungkinkan penarikanan dan pengambilan tindakan. Peneliti berupaya menggunakan cara yang yang menggunakan matriks teks, grafik, jaringan dan bagan, di samping teks naratif.

3. Penarikan kesimpulan atau verifikasi Analisis data kualitatif mulai dengan mencari anti benda-benda, mencatat keteraturan, pola penjelasan, konfigurasi yang mungkin, alur sebab akibat, dan proposisi. Peneliti akan menarik kesimpulan-kesimpulan secara longgar, tetap terbuka dan skeptic namun kemudian meningkat menjadi lebih rinci dan mengakar dengan kokoh.

Kesimpulan tersebut diverifikasi selama proses penelitian. Verifikasi tersebut berupa tinjauan atau pemikiran kembali pada catatan lapangan, yang mungkin berlangsung sekilas atau malah dilakukan secara seksama dan memakan waktu lama, serta bertukar pikiran dengan para pegawai bank untuk mengembangkan intersubjektif. Makna-makna yang muncul dari data harus diuji kebenarannya, kekokohannya, dan kecocokannya, sehingga membentuk validitasnya.

\section{HASIL DAN PEMBAHASAN}

Penelitian ini membahas mengenai perspektif pegawai bank tentang persamaan dan perbedaan sistem kevangan yang ada di bank syariah dan bank konvensional. Data diperoleh dari pengamatan pengamatan fenomena secara seksama bagaimana sistem keuangan yang sesugguhnya terjadi di kedua bank berdasarkan pengalaman pegawai bank yang pernah bekerja di kedua bank tersebut melaui wawancara mendalam yang dilakukan sejak tanggal 15 Maret 2018 sampai 5 Mei 2018.

Jumlah informan yang terlibat berjumlah 13 orang.Informan dalam penelitian ini didapat dengan teknik purposive sampling. Terdapat beberapa kriteria informan dalam penelitian ini, diantaranya:

1. Pegawai bank yang telah berkarir selama minimal 3 tahun.

2. Menempati posisi minimal Middle Manager serta pekerjaannya berhubungan dengan penghimpunan dana, penyaluran dana, dan produk bank.

3. Pernah bekerja di bank syariah dan di bank konvensional. Karena dalam penelitian akan mencari makna dari persepsi pegawai bank yang pernah bekerja di kedua bank tersebut. 


\section{Persamaan Bank Syariah dan Bank Konvensional}

Seluruh informan mengatakan bahwa persamaan yang ada di bank syariah dan bank konvensional jenisnya sama, yaitu tabungan, giro, dan deposito. Tetapi nama produk dari setiap bank bisa berbeda-beda. Bukan hanya anta bank syariah dan bank konvensional, bahkan di setiap bank bank syariah bisa saja berbeda.

Usaha perbankan meliputi tiga kegiatan utama yaitu (Kasmir, 2010):

1. Menghimpun dana.

2. Menyalurkan dana.

3. Memberikan jasa bank lainnya.

Sesuai dengan hasil wawancara, semua informan mengemukakan bahwa bank syariah dan bank konvensional sama-sama menjalankan tugas seperti yang diamanatkan dalam UndangUndang RI Nomor 10Tahun 1998 tanggal 10 November 1998 tentang Perbankan adalah badan usaha yang menghimpun dana dari masyarakat dalam menyimpan bentuk simpanan dan menyalurkannya kepada masyarakat dalam bentuk kredit atau pembiayaan dan atau bentukbentuk lainnya dalam rangka meningkatkan taraf hidup rakyat banyak.

Selain itu, akad pada transaksi di bank syariah berbeda dengan bank konvensional. Perjanjian awal di bank konvensional ditentukan berdasarkan perjanjian pinjam-meminjam vang atau hutang. Sedangkan di bank syariah akad untuk pembelian suatu objek yang sama bisa berbeda-beda. Akad menentukan skema transaksi di bank syariah.

\section{Perbedaan Bank Syariah dan Bank Konvensional}

Bank syariah dan bank konvensional sama-sama perusahaan yang mengejar profit namun cara yang dilakukan oleh bank syariah dan bank konvensional berbeda. Bank syariah menggunakan nisbah atau bagi hasil yang dinilai lebih adil karena melihat kondisi bisnis bank tersebut. Dapat dilihat dari sisi funding, jika keadaan bank sedang baik maka bagi hasil yang diberikan tinggi dan sebaliknya jika kondisi usaha nasaba sedang buruk bagi hasil yang diberikan juga rendah. Berbeda dengan bank konvensional yang menetapkan bunga fix dalam pemberian kompensasi kepasa nasabah yang sudah dijanjiakan diawal tanpa melihat keadaan pendapatan bank sedang baik atau buruk.

Menurut hasil wawancara, informan merasakan bahwa bank syariah berbeda dengan bank konvensional jika dilihat dari sudut pandang agama. Namun dalam praktiknya bank syariah sama saja denga bank konvensional. Jika dilihat dari sudut pandang proses, strukturnya, pengambilan profitnya bank syariah sama dengan bank konvensional. Seperti yang terdapat dalam Jurnal Economic substance or legal form: an evaluation of Islamic finance practice (Hanif, 2016) bahwa bank syariah dan bank konvensional berbeda jika dilihat 
dari sudut pandang agama. Sedangkan secara kontrak dan substansi ekonomi kedua bank ini sama.

\section{Fungsi Perbankan}

Dilihat dari segi agent of trust, Informan mengatakan kepercayaan sering kali bukan karena bank itu merupakan bank syariah atau bank konvensional, tapi lebih ke siapa pemiliknya. Namun jika dilihat jika sesama bank syariah atau sesama bank konvensional, nasabah akan melihat bagaimana bank itu mengelola keuangannya.

Bank konvensional dan bank syariah bahwa kedua bank sama-sama menjalankan dengan fungsinya sebagai agent of development dengan baik sesuai yang diamanatkan dalam dalam Undang-Undang untuk menumbuhkan perekonomian.Bank syariah dan bank konvensional sama-sama menjalankan fungsinya sebagai agent of development dengan baik. Yang membedakan adalah pangsa pasarnya. Bank syariah memiliki fokus ke pangsa pasar usaha-usaha muslim.

Sedangkan dari sisi agent of trust, informan mengatakan bank syariah maupun bank konvensional sama-sama mengedepankan pelayanan karena inti baru perusahaan perbankan adalah perusahaan jasa di bidang keuangan maupun non keuangan. Pelayanan terbaik akan diberikan baik di dalam kantor maupun di luar kantor. Yang menjadi nilai tambah di bank syariah adalah pelayanan-pelayanan yang mempertimbangkan nilai religiusitas. Secara teknis pelayanan di bank konvensional lebih maju daripada di bank syariah. Tetapi saat melaksanakan pemasaran produk ada nilai tambah dari bank syariah. Pegawai bank menanamkan diri agar lebih ikhlas tidak terlalu ditekan target seperti di bank konvensional.

\section{Sistem Kevangan Islam}

Berkaitan dengan pelarangan riba, denda merupakan sanksi yang dikenakan kepada nasabah karena bermasalah dalam pengembalian dana pembiayaan. Jika dilihat beberapa dari beberapa pernyataan diatas, denda merupakan tambahan yang berarti riba. Namun kenyataannya, beberapa bank yang masih menetapkan denda ini memiliki alasan tertentu. Pemberlakuan denda hanya ditujukan untuk memberikan efek jera dan memperkecil kemungkinan nasabah tidak disiplin dalam perjanjian pembiayaan. Denda sifatnya hanya mengikat nasabah agar memiliki tanggung jawab untuk mengembalikan dana. Denda tidak menjadi pendapatan perusahaan tetapi akan disalurkan ke lembaga sosial sehingga bank tidak memanfaatkan vang riba tersebut. Oleh karena itu denda yang dikenakan di bank syariah tidak sebesar dengan denda di bank konvensional yang menjadi pendapatan bank.

Di bank syariah terdapat pelarangan praktik maysir. Sesuai dengan 
yang diungkapkan oleh beberapa informan, produk di bank syariah tidak ada satupun yang mengandung maysir.Maysir atau spekulasi tidak ada jika dilihat secara ketentuan karena semua perhitungan dari transaksi dimulai hingga selesai harus dipaparkan diawal. Berbeda dengan bank konvensional yang memiliki produk mengandung maysir seperti arisan.

Tetapi maysir bisa saja terjadi di lapangan karena dilakukan oleh oknumoknum tertentu salah satunya adalah oknum penjual. Dan pengawasan terhadap oknum tersebut kurang yang mengakibatkan hal tersebut bisa saja terjadi sewaktu-waktu. Dai uraian diatas, dapat disimpulkan bahwa masih ada maysir di bank syariah yang diakibatkan oleh oknum didalamnya.

Prinsip kevangan Islam juga melarang adanya gharar atau ketidakjelasan. Berdasarkan hasil wawancara, produk bank syariah tidak mengandung untur grara. Pegawai bank juga selalu diajarkan untuk terbuka kepada nasabah. Tetapi keterbukaan ini ada batasnya. Tidak semua bisa dibuka kepada nasabah seperti data nasabah lain atau perputaran vang secara detail. Semua keterbukaan dilakukan jika mengenai akad transaksi.

Tetapi ada beberapa pegawai bank yang tidak menjelaskan semuanya saat di lapangan jika nasabah berpotensi untuk membandingkan bank tersebut dengan bank lain. Untuk memenangkan nasabah, mereka tidak selalu memberi tahu karena pasti bank syariah kalah terutama dari segi harga yang mahal. Hal ini dikarenakan persaingan setiap bank. Pelarangan gharar hanya secara ketentuan namun gharar bisa saja terjadi karena oknum didalamnya. Jadi pegawai bank tidak selalu mempraktekkan sesuai teori saat di lapangan.

Profit and loss sharing juga merupakan prinsip keuangan Islam. Pada penelitian ini menemukan alasan mengapa bank syariah masih menggunakan revenue sharing dan belum menggunakan profit sharing. Penggunaan prinsip keuangan Islam revenue sharing ini dipilih bank syariah karena beberapa hal berikut ini:

- Bank sebagai shahibul maal (pemilik dana): pencatatan laporan kevangan nasabah pembiayaan belum bagus dan rasa tanggung jawab nasabah dalam mengembalikan dana masih kurang.

- Bank sebagai mudharib (pengelola dana): revenue sharing lebih accountable di pandangan masyarakat karena bagi hasil akan diberikan dari pendapatan kotor yang tidak dikurangi beban-beban operasional bank.

Selain itu pendanaan di bank syariah harus kepada bisnis yang halal. Seluruh informan sepakat bahwa penyaluran dana yang dilakukan oleh bank syariah mutlak harus kepada bisnis yang halal dan semua kerjasama dengan bisnis tersebut merupakan bisnis yang 
halal. Jika penyaluran untuk pembiayaan konsumtif harus kepada orang yang pendapatan gajinya dari sesuatu yang halal. Berbeda dengan bank konvensional yang dapat menyalurkan dana kepada bisnis apapun tanpa melihat halal dan haramnya.

\section{v. SIMPULAN DAN SARAN}

Makna dan esensi dari persamaan dan perbedaan sistem keuangan bank syariah dan bank konvensional di lapangan dapat diungkapkan dari pengalaman pegawai bank yang pernah bekerja di kedua bank tersebut dengan pendekatan fnomenologi. Bank syariah dan bank konvensional sama dari jenis produk yaitu tabungan, giro, dan deposito dan keduanya memiliki fungsi utama sebagai intermediari yang menghimpun dana masyarakat dan menyalurkan ke masyarakat lainnya. Bank konvensional dan bank syariah merupakan lembaga kevangan yang sama-sama mengejar profit dengan cara yang berbeda.

$$
\text { Sedangkan perbedaannya }
$$
adalah adalah mengenai sistem di masing-masing bank. Bank syariah menggunakan akad dalam setiap transaksinya sedangkan bank konvensional tidak. Dalam pengambilan profitnya, bank syariah menggunakan nisbah dan bank konvensional menggunakan bunga tetap. Bank syariah dan bank konvensional berbeda dari prinsip-prinsip keuangan. Produk bank syariah terdapat pelarangan riba, pelarangan maysir, pelarangan gharar, menggunakan profit and loss sharing, dan pendanaannya untuk bisnis halal. Karena terbatasi oleh peraturaturan syariat Islam, segmentasi bank syariah dinilai lebih kecil dari pada bank konvensional yang bias masuk ke semua segmen. Bank syariah dan bank konvensional berbeda jika dilihat dari sudut pandang agama, sedangkan secara kontrak dan substansi ekonomi kedua bank ini sama

Peneliti memberikan saran kepada perbankan untuk lebih mengontrol dan mengevaluasi kegiatannya agar bank syariah dan bank konvensional berjalan sesuai tugasnya. Peneliti juga memberi pesan kepada pegawai bank akan pentingnya kejujuran dan amanah dalam menjalankan tugas dan tanggung jawab dalam pekerjaannya di setiap bank.

\section{DAFTAR PUSTAKA}

Antonio, Muhammad Syafi'i. 2001. Bank Syariah: Dari Teori ke Praktik. Jakarta.

Gema Insani.

Arif, M. Nur Rianto Al. 2015. Pengantar Ekonomi Syariah Teori dan Praktik. Bandung: CV Pustaka Setia.

Bungin, Burhan. 2015. Metodologi Penelitian Sosisal dan Ekonomi: Format Format Kuantitatif dan Kualitatif untuk Studi Sosiologi, Kebijakan Publik, Komunikasi, Manajemen, dan Pemasaran. Jakarta: Prenadamemdia Group.

Chong, Beng Soon dan Ming-Hua Liu. 2009. Islamic Banking: Interest-free 
or Interest-based?. Pasific-Basin Finance Journal, Vol. 14.

Creswell, John W. 2015. Penelitian Kualitatif \& Desain Riset Memilih di Antara Lima Pendekatan. Edisi Ketiga. Yogyakarta: Pustaka Pelajar.

Dewi, Yannani Mutiara. 2018.Perbandingan Bisnis Model, Stabilitas, Serta Kinerja Kevangan Bank Umum Syariah dan Bank Umum Konvensional di Indonesia Periode 2012 - 2016. Universitas Airlangga: Skripsi Tidak Diterbitkan.

Hanif, Muhammad. 2016. Economic substance or legal form: an evaluation of Islamic finance practic. International Journal of Islamic and Middle Eastern Finance and Management, Vol. 9 , No. 2.

Hasan, Zulkifli Bin. 2016. From legalism to value-oriented Islamic finance practices. Humanomics, Vol. 32, No. 4.

Hermansyah. 2008. Hukum Perbankan Nasional Indonesia. Jakarta: Prenada Media Group.

Huda, Nurul dan Mohamad Heykal. 2010. Lembaga Keuangan Islam: Tianjauan Teoritis dan Praktis. Edisi Pertama. Jakarta: Kencana Prenada Group.

Ismail. 2012. Model Bisnis Perbankan Syariah. Kajian Direktorat Perbankan Syariah Bank Indonesia.

Karim, Adiwarman. 2014. Bank Islam: Analisis Fiqih dan Keuangan. Jakarta: Raja Grafindo Persada.
Kasmir. 2010. Dasar-dasar Perbankan. Jakarta: Rajawali Pers.

Kasmir. 2010. Manajemen Perbankan. Jakarta: Rajawali Pers.

Kholvadia, Faatima. 2017. Islamic Banking in South Africa - Form Over Substance?. Meditari Accountancy Research, Vol. 24, No.1.

Kuswarno, Engkus. 2013. Metode Penelitian Komunikasi Fenomenologi Konsepsi, Pedoman, dan Contoh Penelitiannya. Bandung: Widya Padjadjaran.

Latumaerissa, Julius R. 2012. Bank dan Lembaga Kevangan Lain. Jakarta: Salemba Empat.

Mardani. 2015. Aspek Hukum LembagaKeuangan Syariah di Indonesia. Edisi Pertama. Jakarta: Prenadamedia Group.

Muhamad. 2016. Manajemen Pembiayaan Bank Syariah. Edisi Kedua. Yogyakarta: UPP STIM YKPN.

Shihab, M. Quraish. 2002. Tafsir Al-Misbah Pesan, Kesan dan Keserasian Al Qur'an. Vol. 1. Jakarta Pusat: Lentera Hati Jakarta: Raja Grafindo Persada.

Sudarsono, Heri. 2003. Bank \& Lembaga Keuangan Syari'ah Deskripsi dan Ilustrasi. Yogyakarta: Ekonisia.

Sugiyono. 2015. Memahami Penelitian Kualitatif. Bandung: Alfabeta. 
Suratno, Thomas dkk. 2005. Kelembagaan

Perbankan. Edisi Ketiga. Jakarta:

Percetakan PT SUN.

Umam, Khotibul. 2017. Perbankan Syariah:

Dasar-Dasar dan Dinamika

Perkembangannya di Indoensia.

Depok: PT Rajagrafindo Persada.

Usman, Rachmadi. 2012. Aspek Hukum

Perbankan Syariah di Indonesia.

Jakarta: Sinar Grafika.

Yusuf, Muri. 2014. Metode Penelitian:

Kuantitatif, Kualitatif, dan Penelitian

Gabungan. Edisi Pertama. Jakarta:

Prenadamedia Group. 